DOI: 10.12731/2658-4034-2020-1-50-53

\title{
ИНТЕРАКТИВНЫЕ МЕТОДЫ ОБУЧЕНИЯ КАК СРЕДСТВО ФОРМИРОВАНИЯ ПРОФЕССИОНАЛЬНЫХ КОМПЕТЕНЦИЙ СТУДЕНТОВ ВЫСШИХ УЧЕБНЫХ ЗАВЕДЕНИЙ ПРИ ОВЛАДЕНИИ КУРСОМ «АЛГЕБРА И АНАЛИТИЧЕСКАЯ ГЕОМЕТРИЯ»
}

\section{Puxmep T.B.}

Пермский государственный национальный исследовательский университет, г. Соликамск, Пермский край, Российская Федерация

В статье выявлены интерактивные методы обучения, влияющиче на формирование профессиональных компетенций студентов вузов при овладении курсом «Алгебра и аналитическая геометрия».

Ключевые слова: интерактивные методы обучения; профессиональные компетенции; формирование профессиональных компетенций; курс «Алгебра и аналитическая геометрия»; студенты высших учебных заведений.

\section{INTERACTIVE TEACHING METHODS AS A MEANS OF FORMING PROFESSIONAL COMPETENCIES OF STUDENTS OF HIGHER EDUCATIONAL INSTITUTIONS WHILE MASTERING THE COURSE «ALGEBRA AND ANALYTICAL GEOMETRY»}

\section{Richter T.V.}

Perm State University, Solikamsk, Perm Region, Russian Federation

The article identifies interactive teaching methods that affect the formation of professional competencies of university students in mastering the course "Algebra and Analytical Geometry». 
Keywords: interactive teaching methods; professional competencies; formation of professional competencies; course "Algebra and Analytical Geometry»; students of higher educational institutions.

\section{Введение}

Одна из актуальных проблем системы высшего образования заключается в определении эффективных способов формирования профессиональных компетенций студентов, что обусловлено необходимостью подготовки конкурентоспособных специалистов, удовлетворяющих требованиям современного рынка труда. К эффективному инструментарию их формирования можно отнести интерактивные методы обучения, направленные на процесс продуктивного межличностного взаимодействия через внешний диалог с предоставлением возможностей для саморазвития и самореализации.

Цель исследования: выявить интерактивные методы обучения, влияющие на формирование профессиональных компетенций студентов вузов при овладении курсом «Алгебра и аналитическая геометрия».

\section{Материалы и методы исследования}

Ведущими методами исследования явились обобщение и анализ научных трудов по теме исследования.

\section{Результаты исследования и их обсуждение}

Профессиональные компетенции можно определить как способность, свойство, качество или характеристику личности.

Анализ научной литературы (Н.Н. Двуличанская, М.Д. Ильязова, Е.А. Кагакина, Ю.Г. Татур, Т.А. Чекалина) позволил выделить в структуре профессиональной компетенции следующие составляющие: ценностную, организационно-мотивационную, знаниевую, операционно-деятельностную, индивидуально-психологическую, социальную, оценочно-рефлексивную, коррекционную.

Профессиональные компетенции могут формироваться через интерактивные формы учебно-практических мероприятий (лекции и семинары и др.) [3]. Особенности их использования описаны в работе Л.Г. Шестаковой [2]. 
Анализ педагогической литературы по проблеме исследования позволил выявить интерактивные методы, способствующие формированию структурных компонент профессиональной компетенции при изучении курса «Алгебра и аналитическая геометрия» (таблица 1) [1].

Таблица 1.

$$
\begin{gathered}
\text { Интерактивные методы, способствующие формированию } \\
\text { структурных компонент профессиональной компетенции при изучении } \\
\text { курса «Алгебра и аналитическая геометрия» }
\end{gathered}
$$

\begin{tabular}{|c|c|c|}
\hline \begin{tabular}{|c|} 
Компоненты \\
професси- \\
ональной \\
компетенции \\
\end{tabular} & $\begin{array}{c}\text { Интерактивные } \\
\text { методы }\end{array}$ & $\begin{array}{c}\text { Разделы курса } \\
\text { «Алгебра и ана- } \\
\text { литическая гео- } \\
\text { метрия» } \\
\end{array}$ \\
\hline $\begin{array}{l}\text { Ценност- } \\
\text { ный }\end{array}$ & $\begin{array}{l}\text { Организационно-мотивационные (дискуссия по } \\
\text { теме «Тригонометрическая форма комплексного } \\
\text { числа», «Деление комплексных чисел») }\end{array}$ & $\begin{array}{l}\text { Комплексные } \\
\text { числа }\end{array}$ \\
\hline $\begin{array}{l}\text { Организаци- } \\
\text { онно-моти- } \\
\text { вационный } \\
\end{array}$ & $\begin{array}{l}\text { Организационно-мотивационные (диалог по } \\
\text { теме «Приведение матриц к ступенчатому } \\
\text { виду») }\end{array}$ & Матрицы \\
\hline Знаниевый & $\begin{array}{l}\text { Когнитивные (презентация по теме «Нахожде- } \\
\text { ние определителей», интерактивная игра по теме } \\
\text { «Нахождение обратных матриц», эвристическая } \\
\text { беседа по теме «Вычисление определителей, } \\
\text { используя их свойства», круглый стол по теме } \\
\text { «Вычисление определителей разложением по эле- } \\
\text { ментам первой строки») }\end{array}$ & Определители \\
\hline $\begin{array}{l}\text { Операцион- } \\
\text { но-деятель- } \\
\text { ностный }\end{array}$ & $\begin{array}{l}\text { Операционно-деятельностные (мозговой штурм } \\
\text { «Метод Гаусса как метод решения систем линей- } \\
\text { ных уравнений», деловая игра по теме «Метод } \\
\text { Крамера и системы линейных уравнений») }\end{array}$ & $\begin{array}{l}\text { Системы ли- } \\
\text { нейных уравне- } \\
\text { ний. Линейные } \\
\text { пространства }\end{array}$ \\
\hline \begin{tabular}{l|} 
Индивиду- \\
ально-психо- \\
логический \\
\end{tabular} & $\begin{array}{l}\text { Социально-психологические (коллективное ре- } \\
\text { шение творческих задач по нахождению скаляр- } \\
\text { ного произведения векторов) }\end{array}$ & $\begin{array}{l}\text { Элементы век- } \\
\text { торной алгебры }\end{array}$ \\
\hline $\begin{array}{l}\text { Социаль- } \\
\text { ный }\end{array}$ & $\begin{array}{l}\text { Социально-психологические (разминка по теме } \\
\text { «Взаимное расположение прямых на плоско- } \\
\text { сти», «Взаимное расположение плоскости и пря- } \\
\text { мой в пространстве») }\end{array}$ & $\begin{array}{l}\text { Прямая на пло- } \\
\text { скости. Пло- } \\
\text { скость и прямая } \\
\text { в пространстве }\end{array}$ \\
\hline $\begin{array}{l}\text { Оценочно- } \\
\text { рефлексив- } \\
\text { ный }\end{array}$ & $\begin{array}{l}\text { Оценочно-рефлексивные (групповая дискуссия } \\
\text { по теме «Нормированные вектора евклидова } \\
\text { пространства», тест по разделу «Евклидовы и } \\
\text { унитарные пространства») }\end{array}$ & $\begin{array}{l}\text { Евклидовы и } \\
\text { унитарные про- } \\
\text { странства }\end{array}$ \\
\hline $\begin{array}{l}\text { Коррекци- } \\
\text { онный }\end{array}$ & $\begin{array}{l}\text { Коррекционные (работа в малых группах по } \\
\text { устранению пробелов в знаниях при изучении } \\
\text { раздела «Билинейные и квадратичные формы») }\end{array}$ & $\begin{array}{l}\text { Билинейные и } \\
\text { квадратичные } \\
\text { формы }\end{array}$ \\
\hline
\end{tabular}




\section{Заключение}

Использование выделенных интерактивных методов в курсе «Алгебра и аналитическая геометрия» будут способствовать формированию профессиональных компетенций и повышению качественного уровня образовательного процесса.

\section{Список литературы}

1. Рихтер Т.В. Формирование профессиональных компетенций студентов высшей школы в условиях использования интерактивных методов обучения Теория и практика общественного развития. 2015. № 22. C. 254-256.

2. Шестакова Л.Г. Активные и интерактивные методы в обучении студентов-педагогов // Активные и интерактивные методы обучения в естественно-математическом образовании: коллективная монография. Соликамск: СГПИ, 2018. С. 38-45.

3. Shestakova L.G., Kharitonova Y.A., Rikhter T.V. Assessing activity of pedagogical college students as a study activation tool // Indian Journal of Science and Technology. 2016. T. 9. № 21. C. 95221.

\section{References}

1. Rikhter T.V. Formirovanie professional'nykh kompetentsiy studentov vysshey shkoly v usloviyakh ispol'zovaniya interaktivnykh metodov obucheniya Teoriya i praktika obshchestvennogo razvitiya. 2015. № 22. S. 254-256.

2. Shestakova L.G. Aktivnye i interaktivnye metody $v$ obuchenii studentovpedagogov // Aktivnye i interaktivnye metody obucheniya $\mathrm{v}$ estestvennomatematicheskom obrazovanii: kollektivnaya monografiya. - Solikamsk: SGPI, 2018. S. 38-45.

3. Shestakova L.G., Kharitonova Y.A., Rikhter T.V. Assessing activity of pedagogical college students as a study activation tool // Indian Journal of Science and Technology. 2016. T. 9. № 21. S. 95221. 